\title{
The Interior-the Source of the Truth and Individuality of the Person
}

\author{
And yet it is a true doctrine; \\ for truth is not on the surface of things, \\ but in the depths. \\ JOHN HENRY NEWMAN \\ This implies that only the religious attitude \\ is truly ethical. \\ EDITH STEIN
}

Edith Stein studies the sphere of individuation in her monumental book Finite and Eternal Being. What makes an individual being individual? What are the elements that are shared by all beings and what are the distinctive features that can be ascribed to this being only and not to others? An answer to these questions is of utmost importance especially for such a being as person. As we have seen the solution here is crucial for Newman, for it decides about our notional or real cognition. Person is a human being, one of many other human beings, when we consider his shared features. Nevertheless, "what the individual thing is above and beyond its universally conceivable nature is its exclusive and immediate property." In other words there is infinitely more to the person than his shared properties, therefore "individuality as such has been designated as noncommunicability." I have already written about individuality that is attendant on each individual being as such, irrespective of his capability of expression. Besides, in view of the above statement, the attempts to

1 E. Stein, Finite and Eternal Being: An Attempt at an Ascent To the Meaning of Being, trans. K. F. Reinhardt, Washington, D.C.: ICs Publications Institute of Carmelite Studies, 2002, 469. 
show individuality, let alone to impress others with our individuality, are futile because in its deep sense it is incommunicable!

John Crosby describes it precisely when he writes: "Insofar as we live as incommunicable persons, we live in a way hidden from others. I live in my interiority, or subjectivity, to which others do not have access as I do, I am present to myself at the center of my subjectivity in a way in which no other person can be present to me, just as any other person is present to himself in a way in which I can never be present to him. Another person would have to be me if he were to stand in that place where I stand in experiencing myself." I may obviously inform others about myself, but this does not change the fact that they learn about me through the mediation of the language. And I am the one who controls what I want to say, I am the interpreter of myself.

\section{Individuality versus the Transcendental Area}

We share with other beings the universal essence or nature. "But what is that," asks Stein, "which the individual thing shares with no other thing, that which makes it an individual thing?"3 I think that here we encroach upon the sphere of Newman's egotism, of his natural reasoning and inference, the idiosyncratic perception and personal result. They are best reflected in real assent. For it is in real assent that we observe an individual symmetry between the knowing subject and the object of knowing. Stein speaks about "inner non-dividedness" and "unity or oneness." We must remember, however, that we are referring here to the transcendental area in which all other beings share, i.e. they share in undividedness as being separate from other meaningful structures. What every human being participates in does not make him different from other human beings in the sense of this human being. In Newman's terms, we are still on the notional level, and Edith Stein rightly concludes that "this is why the transcendental unity does not suffice to define and determine the nature of individual being."

The transcendental unity does not suffice to display the uniqueness of this concrete being, neither does it suffice to point at numerical unity. Indeed this kind of unity is opposite to multiplicity, which is composed of numerical units. Each human being expects to be respected in his or her individuality rather

2 J. Crosby, Personalist Papers, Washington D.C.: The Catholic University of America Press, 2004, 33-34.

3 E. Stein, Finite and Eternal Being, 470.

4 Ibid. 
than universality. Stein notes that "The generic nature of matter as such makes possible the co-existence [Nebeneinander] of things that are alike. However, this generic nature is not the ground or the root principle of individual being, but that which is required by the form.

Not the essential form but only the pure form or the essence [...] of which things 'partake' by their essential form is what is 'communicable' to a multitude of individual things. ${ }^{5}$ And it is not matter that can be translated into a means of communication. Stein continues her description: "Matter as such, to be sure, is not communicable at all. In itself and by itself it has neither meaning nor efficacy - neither something which could be communicated nor the power to communicate. It is simply that which receives, partakes, and is divisible." 6 The essential form is incommunicable, it is individual 'in itself'. Edith Stein further explains: "But the mere being-individual of one thing — as far as the content is concerned-differs not at all from the being individual of another thing. The being individual pertains to the empty form of the thing. If two individual things are to be distinguished as this or that, they must have something distinctive above and beyond their being individual. In the case of material things that are alike, this element of distinction is their share in matter [Stoffanteil] by which they differ spatially from each other. We have to ponder the question whether in the case of individual things of a different genus this share in matter is replaced by something else."7

Stein attributes individual being also to the form, for the form cannot be without matter. The meaning of the form is the forming of matter.

If essential form is incommunicable, then there is no point in exerting oneself in communicating what cannot thus be communicated. After all what one does manage to communicate must be something else than essential form. Ideal objects, like triangles, can only be distinguished by their position in space. The triangle is not an individual thing because its being a triangle is shared by all other triangles. It has a meaningful structure, for it can be distinguished from other meaningful structures, but "it lacks the full determinateness which is required for independence."

Let us make use of some literary examples. We know the story of the Little Prince from a world-famous booklet by Antoine de Saint-Éxupery. The Little Prince looked at the roses in a garden and wept in sorrow because he looked at them merely as instances of the same species, i.e. the individual form that

5 Ibid., 486.

6 Ibid.

7 Ibid.

8 Ibid., 487 . 
was empty. He looked at them theoretically and notionally without noticing any distinctive feature that could guide him onward to a personal attachment. Indeed there is no attachment in transcendental acquiescence. All flowers of the same species are the same and all shapes are the same, therefore they are of no distinction. And the Little Prince sought something distinctly individual.

He desperately searched for some distinctive signs in what was visible and external, and found nothing. There might have been some variations, e.g. some petals were larger than others, the contours of their outlines curved at different angles, and the shades of colours differed. But these were minor differences; they were, so to say, quantitative and countable differences. The lesson he received from the Fox suggests to reverse perception, to look within rather than without, to look at the traces of mutual experience left inside. Even the relationship between two individual beings is rooted within because it is not a relationship between two inanimate objects, related to each other in terms of spatial and temporal positions. Transcendental perspective leads to frustration and scepticism; personal perception leads to attachment and suffering. And suffering is the main ingredient of human life. If there is no personal commitment, everything seems dull.

St Thomas Aquinas wrote in his Summa: "For it is clear that whatever is received into something is received according to the condition of the recipient. Now a thing is known as far as its form is in the knower." ${ }^{\text {A }}$ Aquinas means the metaphysical mode of reception. In like manner it is metaphysical in the sense of unity. And this sense is notional and theoretical.

Indeed the sense of a detail is in the whole to which the detail serves. It is likewise with Christianity or any other great idea-it must be considered in its overall integrity, in its historical development. Only then can the individual elements be accounted for.

\section{$2 \quad$ Communicability versus Non-communicability}

In the case of material and individual objects "we must distinguish between the being-different $[\ldots]$ and the being-distinguishable-in-its-difference $[\ldots]$. $[\ldots]$ The knowability of differences rests, in the case of material things, on their participation in matter, and in the case of pure geometrical structures it rests on their position or location in space. In both instances this knowability has its

9 Aquinas, Summa Theologica, translated by Fathers of the English Dominican Province, New York: Benziger Brothers, Inc., 1947, q. 75, art. 5. 
foundation in the spatial nature of objects." ${ }^{10}$ It is the nature of the carrier that is the ground or foundation of individual being. For Thomas Aquinas, the root principle of differentiation is matter. Now for Stein, "the personal carrier is the ground or root principle of individual being. And since we do not find the root principle of individual being in the 'communication' or, more precisely, in the self-molding of the form into space-filling matter, but see in this a kind of communication [...], rather than the unfolding of the essence of a definite genus of forms, the 'non-communicability' [...] of spiritual forms to space-filling matter constitutes $[. .$.$] no proof of the non-communicability of the determinateness$ of the species to a multiplicity of individuals." 11

Edith Stein compares human life to a melody which, when played, each sounds differently. The melody is a person's " $<$ course of life $>$ as a time structure."12 It cannot be played exactly in the same manner, for at each time it springs uniquely. "The person is a carrier in a different sense than any impersonal something. The life of the person 'springs' from personal being as from a source, and it is conceivable that this life might end without the person itself being annihilated, and the person might then begin a new life."13 I find this musical metaphor particularly attractive when used as an analogy to human life.

The root principle of individual being is found in the formal structure of objects "and especially in the fact that the carrier which confines or sets apart the essence or nature of objects as their empty form is not communicable."14 The carrier is like an abyss from which the essence springs forth. Under the external influences material individual things manifest differences. Together with the determinateness of the species they are "responsible for the 'fate' of individual things and their particular actual formal structure."15

\section{The Human Being}

Now with regard to human beings, the situation becomes much more complicated. The human being is also a composite of form and matter, hence in this respect he is "an essence or nature that is always and everywhere the

\footnotetext{
10 E. Stein, Finite and Eternal, 492.

11 Ibid., 493.

12 Ibid., 494.

13 Ibid., 495 .

14 Ibid., 496.

15 Ibid., 497.
} 
same."16 At the same time one concrete human being is entirely unlike other human beings. What makes him distinct from other human beings? Edith Stein answers: "The individuals are carriers of the particularity of the species and of the specific formation which is achieved with the aid of external circumstances. The material constitution of the individual being and of the environment into which the individual is integrated are co-determining factors." ${ }^{17}$ This concrete individual results from its natural endowment-matter shaped by form - and the interaction of the environment, interrelations, i.e. ethos. In other words, we perceive this peculiar duality in each human being, i.e. it follows the mode of development of animals and plants, and at the same time there is something infinitely more that is being added to it. Aside to this "natural" aspect shared by all beings, human life is "a spiritual, personal, internal life that discloses itself to fellow humans and that is ever renewed from these sources; and, lastly, a life that is freely determined by the I-then we must ask whether this radical dichotomy of human life is not also of major significance for the individual being and the individual particularity of human beings."18

Obviously today we know much more about this natural fortune of all beings than it was known in the time of Edith Stein. We have decoded the human genotype and we know that as far as the biological aspect of our nature is concerned we do not differ much from animals. The conclusion is henceforth obvious: it is not in biology that one should seek the root principle of human peculiarity and individuation. And here we arrive at what Newman called the infinite abyss of our existence, as we have already quoted it here.

The Life-Emanating I

Life "emanates from the I and [...] the personal I holds command over it in a dual sense: so as to become conscious of it as of a life that is set apart from everything else; and so as to mold this life freely."19 The I is not a pure ego. Stein rises to the heights of phenomenological description that borders on poetry when she writes that "the pure ego is, as it were, only the portal through which the life of the human person passes on its way from the depth of the soul to the lucidity of consciousness. And the inmost center of the soul, its most authentic and most spiritual part, is not colorless and shapeless, but has a particular form

\begin{tabular}{ll}
\hline 16 & Ibid., 50o. \\
17 & Ibid., 501. \\
18 & Ibid. \\
19 & Ibid.
\end{tabular}


of its own." ${ }^{20}$ Sarah Borden recapitulates this essential element of Stein's elaboration on individual form. From her interpretation we learn that "each human being has an a priori content-rich individual form [...], a form which provides a structure for our individual development and therefore limits our individual possibilities."21 Then the commentator goes on to characterise the personalism of her heroine as follows: "Stein insists that each of us has a unique personal core that characterizes us and is permanent, abiding unchanged throughout our lives under any and all circumstances. It does, however, unfold and imprint our actions and lives ever more deeply. We could return to the image of the flower. Just as a flower begins closed and only gradually opens to the sun, so our personal core begins tucked within itself and only gradually blooms out in our mental, sentient and physical life."22

This fountain of internal life is marked with personal uniqueness and it is the undying source of individual life. Not only do we find inside the source of our personal life, but also the source of our individual responsibilities. There is always something unique for men and women, for husbands and wives. Individually, they tend to be dispersed in quest of a lifetime career, not because they find it inside, but because they can see others fervently seeking their perfection in careers.

The real centre of individual life is inside, in the innermost part of the human being. It is not a shapeless source, it is somehow-mysteriouslyprimordially shaped and imparts its individual character on the human being. Deep down inside every human being is a pure light and then it radiates gushes forth outside. Now when man retains authenticity and reality in his life the ray of light is clear. It is like a system of mirrors. As long as they are clean they convey the ray to the surface. Not only are they clean but also tilted at correct angles. It is like breathing deeply. I think that now we understand better Newman's idea of the first thoughts and their importance, especially when they concern obedience to conscience. He is afraid of any negative intrusions from outside, any attempts at rationalization that may blur the original clear message from inside, that may contaminate the purity of the source. Or, to use another image, it is like a cluttered flat in which it is difficult to move around. You can only wobble unsteadily to the entrance.

Therefore when Stein writes about the soul that is most authentic when "self-collected," this term immediately refers us to Newman's wholeness. And it

20 Ibid.

21 E. Stein, Thine Own Self. Individuality in Edith Stein's Later Writings, Washington D.C.: The Catholic University of America Press, 2010, 201.

22

S. Borden, Edith Stein, 38 . 
is inside, in this innermost centre of the soul that is composed the root principle of our individuation. It "cannot be grasped in such a manner that it could be given a universal name, nor can it be compared with anything else."23 This is what I have already written before. We become our true self and genuinely individual not when we go out and translate our selves in numerous expressivist forms, but rather when we go inside. The centre lies deeper than character traits, therefore it cannot be reduced to them. A conclusion that we can draw from this fact is clear: what we learn about the human person mediation of his or her character traits is still not his or her true self.

The innermost centre impresses its stamp on every trait of character. Hence there are some vestiges of this centre in the outer expression. We find it in someone's character and attitudes. In our encounters with others we must be aware that behind what appears on the surface there is this deeper stratum, which is "the key that unlocks the mystery of the structural formation of the character of a human being." ${ }^{24}$ Behind the words and appearances there appears the abyss of the person's mystery. Newman's motto ex umbris et imaginibus in veritatem renders the situation I am talking about perfectly. We somewhat feel "the ineffable of the soul's essence also in our communication with others." 25

Another thing that is interesting in this context is that very often one person behaves in a similar manner to another person. This happens especially in the relationship with some model characters or strong personalities in which case one tends to imitate someone else. Although the essential difference in, say, two individuals cannot be grasped, "each of these persons feels himself in his innermost essence as an 'authentic individual' and is so regarded by those who have truly 'grasped' or 'apprehended' the nature of his personality." ${ }^{26}$ This feeling here is of a special kind, for it has a cognitive value. It is "a spiritual act, a spiritual apperception." And Stein continues that this act is called a feeling because it is "a 'dim' apprehension, an apprehension that lacks the clarity and distinctness of a conceptually expressible, rational insight, and because it is an 'apperception in which the heart is engaged."'27 The cognitive feeling is an efficient response to values. The Samaritan saw the wounded man and took pity on him. The Samaritan was moved, yet it was not a mere emotion, but an experience that led to action. It was not a superficial excitement, but an encounter

$\begin{array}{ll}23 & \text { E. Stein, Finite and Eternal, } 501 . \\ 24 & \text { Ibid., 502. } \\ 25 & \text { Ibid. } \\ 26 & \text { Ibid. } \\ 27 & \text { Ibid., 503. }\end{array}$


which effected the mobilization of the person. ${ }^{28}$ There is an essential cooperation in the integrated person between the two cognitive faculties: the intellect and the heart. The heart recognizes what should be done and the intellect suggests how it is to be done. The integrated person-which is another phrase for being united, using real words, and acting in conformity with a well-informed conscience-rushes to apply the means to what he has recognized as his call for duty.

And here we arrive at the core of this intellectual kinship between Newman and Stein, for we are in the sphere of implicit thinking, in the language of the heart. This is the land in which cor ad cor loquitur, not with words but with internal feelings. It is here that the inwardness of one soul- to use Stein's vocabulary-speaks to the inwardness of another soul. This is what I said in another context: the conceptual apprehension becomes inadequate hence we turn to apperception, for we need to see. What is apprehended is something unique and spiritual. It is not accessible to the senses although it pertains to them. And it may be deceptive, just like sense data, but we have to accept it as it is. Therefore, like for Newman, the attitude of doubt is out of place because to dispense with this apperception "altogether [...] would be just as unreasonable as to renounce completely the use of the senses as a means of knowledge on account of the fact that the senses are 'delusive."'29

For Newman, too, to dispense with sense perception on account of the senses being at times deceptive would be of no use. In like manner we have arrived at something of universal validity. Edith Stein proposes to formulate this universality. We feel that our own essence of nature as well as the essences of others are thus constituted. And this "thus" has universal validity. "The reason for this lies in the formal structure of the person: in the uniqueness of the I as such that is conscious of its own self, that embraces the particularity of its own essence as its 'very own', and that ascribes to every other I the same uniqueness and individual particularity." ${ }^{30}$ We cannot apprehend the content of the "thus." When the heart speaks unto the heart it is the dialogue of interrelation rather than an intellectual intercourse.

\footnotetext{
28 See Lk 10:25-37.

29 E. Stein, Finite and Eternal, 503.

30 Ibid.
} 
Let us draw in passing yet one more important conclusion. If the root principle of our individuation is inside in primeval life, it is inherently counterrevolutionary. The true self is inside, not in external forms, therefore the external forms cannot essentially thwart the outward expression of the self. This is the moment of positive freedom-people can be inwardly free irrespective of the political system in which they live. Consequently, the self cannot lay the blame of its inadequacy on social institutions. They are merely—as Newman would say-the circumstances. In concrete situations they may become hindrances, but never determining factors. It would be futile to demolish the external institutions in order to help the self unfold its potentialities and its individuality, for its individual core resides in its innermost recess where the outside has no access. And even if we found some good models for us to imitate, it would be of no help unless we have made an internal reconciliation with the inside.

Newman found his decision to join the Catholic Church in 1845 as personally irresistible, but he would never recommend it to his followers. There is no objective form that can be applied by every person. What is objective must be made personal by the individual work of each person. The practical implementation of this requirement is indeed fascinating both in Newman and Stein, i.e. how to translate the objective into the personal, how a dogma can become a personal principle. The truth flows from inside and from any outside promptings; and even if there are external promptings, they must be sifted through the personal I. Here Newman's sermons on ostentation should be recalled again. Newman suggested acting within the scope of the Church authority as a safeguard against ostentation, for we read: "[God] bids us unite together in one, and to shelter our personal profession under the authority of the general body. Thus, while we show ourselves as lights to the world far more effectively than if we glimmered separately in the lone wilderness without communication with others, at the same time we do so with far greater secrecy and humility."31

This is not to say that we should be recluses. Efforts to become recluses would boil down to ostentation - an outcome that Newman definitely rejected. If our true difference is inside, then individuality should show up as a spontaneous process. Therefore the main activity here is not to run away from other people, that would definitely be wrong, but to go inside; so that even amidst fervent activities we can hold on to the emanating source of our selves. It is like sitting and warming up at our private fires. After all, Newman elucidates, the first duties of a Christian in the order of duties are "to repent and to believe." ${ }^{32} \mathrm{We}$

31 J. H. Newman, Parochial and Plain Sermons, 99.

32 Ibid., 103. 
should for instance discountenance evil by silence and be very cautious when called to pass judgements. This primeval (personal) life inside is like a serene and undisturbed source of stream. By analogy, we may compare this internal journey to the sources from which the imagination of the heart emanates to Newman's journey to the sources of Christianity.

Primeval life has no form - this formula denotes that we cannot account for all the contents of our selfhood in explicit terms, therefore it runs counter the modern tendency. To acquiesce to the return to primordial life means to consent "that essential difference [Wesenunterschied] in individuals cannot be grasped." ${ }^{33}$ This is what in other words means incommunicability. Now to refer to Newman - when he says "I am one," in this word "one" he grasps the implicit and explicit elements of the person, therefore things that can be understood (and communicated) and things that cannot be understood (or communicated). Argumentation is needed in discourse and marks the power. It creates an elusive impression that one rules over reality, whereas what we are dealing with in naming is only the verbal trace of reality, abstracted from its essence. The true reality is in the hidden space, in the unnamed depth where man lives rather than speaks about life. Therefore in this interpersonal communication between two hearts we are so close to a mystic experience. In mystic experience, we go contrariwise, i.e. we abstain from touching, consuming, and feeding the senses. It is like shutting the camera and putting it aside.

The real difference between two people is hidden, any resemblance being only external. Our selves are "unrepeatable." ${ }^{4}$ Now the interesting point is that this innermost difference, that cannot be grasped, is in fact what makes authentically individual. In other words we are not different from other people in the way we describe ourselves and say how different we are, but we are different with regard to the profound ontic sphere of our very being. There is "radical difference of individual essences" and these essences are not placed in matter.

What Newman called real apprehension, Stein names apperception. The relation between apprehension and apperception is such that the latter denotes that "something spiritual and as such not accessible to the senses, even though it manifests itself by means of sensible signs [...]."35 And apperception may be deceptive, just like assent is sometimes deceptive. But Stein, just as Newman, does not dispense with the senses although they at times are erroneous. She does not propose bracketing on that account. Let me remind the reader that Newman opposes doubt as an instrument to arrive at what is indubitable. In

\footnotetext{
33 E. Stein, Finite and Eternal Being, 502.

34 Ibid.

35 Ibid., 5 ०3.
} 
the Philosophical Notebook we read: "If our consciousness < perception> of our existence is to be taken as true and trusted, then our consciousness < perception $>$ of something external to us, answering both to phenomena \& to typical principles or ideas is true and to be trusted. We must take ourselves for what we are - we cannot divide between the mind \& its gifts - we only know the mind through its gifts \& powers." ${ }^{36}$ We have to use ourselves, our faculties, in learning about the world because in the concrete we do not find any generalized conception of the human being, but this living creature in whom all the dimensions and faculties are placed together. Newman opposes any duality between the soul and the body.

The I is unique, for it imposes unity on the person. The I "is conscious of its own self [...], embraces the particularity of its own essence as its 'very own', and that ascribes to every other I the same uniqueness and individual particularity [Eigenheit]."37 But we cannot apprehend and express the content of the "thus" in the phrase "thus constituted," as I have written in the previous paragraph. I think we have some reason to identify the word "thus" with the analysis of "ergo" in Chapter 2. As we remember "ergo" used in implication can be grasped intuitively, say, implicitly. The "ergo" is not merely an intellectual element, nor the "thus" is.

In view of all this we arrive at personalism in Newman and Stein because for personalists - as John Crosby rightly observed — "a human person [is] a creature of interiority, does not exist just to provide an instance of the human kind, but exists as this unrepeatable person and so stands in a sense above the human kind, being always more than an instance of it."38 Another thing of capital importance is that Newman speaks about the mind of the Church. There are truths in this mind in their latent and implicit form, which it takes time to be explicitly formulated. The ideas that have life hardly ever have their explicit form, but nevertheless they actuate their reality by influencing people, "so that we shrink from principles in substance, which we acknowledge in influence."39 This is an interesting point in Newman. Logically speaking, if these ideas are latent one can hardly expect them to be well-defined. They exert their influence by possessing and guiding, as I have said before.

It must be noted that this turn to the subject means precisely the turn to what is profoundly hidden in the subject, not to what can be externally displayed by the subject. The external may be dissipation what God planted in us.

$36 \quad$ E. Sillem (ed.), The Philosophical Notebook, vol. 2, 30.

37 E. Stein, Finite and Eternal Being, 503.

38 J. Crosby, The Personalism of John Henry Newman, XX-XXI.

39 J. H. Newman, University Sermons, 325. 
It is safe to start this inward journey armed with the armoury of the teaching of the Church and personal endowment. Otherwise we can get lost in ostentation and display, i.e. in the same artificial forms. It is like groping in the dark for some indefinite objects.

The difference between the modern turn to the subject and Newman's turn is that modernity rested on the logical structures of thinking with which to define and render the subjective contents in explicit forms. Only these contents are rational in the subject which can thus be rendered. Newman proposes to go further down.

The Little Prince, to use our literary illustration, is on an inward journey with some simple rules as his guiding principles: friendship and love. On his journey inside he meets various inauthentic characters who like shipwrecks sank on the shallow ground of conceit, pride, and addiction. The true (genuine) source of variety is deep down inside the person, in the impenetrable and ineffable abyss. The point is not to give voice to one's private opinion, but to the true self inside. This is the main idea of subjectivity in Newman and Stein, which is put forward by the Fox in Exupéry's novel: "What is essential is invisible to the eye."40

\section{6}

\section{The Source of the Person's Dignity}

In his discussion with Paul Ramsey, I agree with John Crosby that the dignity of "the human persons is in part grounded in their immanent makeup."41 This position converges with Newman's implicit knowledge and Stein's innermost source of the human mystery. And for Crosby this is the main source of dignity; it is not "that treatment of a person which is appropriate to him or her as person, but rather that in a person in virtue of which some treatment is appropriate and other treatment is inappropriate." ${ }^{22}$ This dignity is related to the person's self-possession, not in the sense of being aware of this self-possession, so Crosby does not mean "this consciousness of one's dignity but with the dignity of which one is conscious." 43

This dignity emanates from the depth of the human person. I also agree with Crosby-in view of what I have read about Newman's and Stein's personal approach - that rationality varies from one being to another. Thinking is a personal process. We are not of one replicable template. Crosby notes: "This

\footnotetext{
40 See A. de Saint-Exupéry, The Little Prince, trans. K. Woods, London: Heinemann, 1974, 72.

41 J. Crosby, Personalist Papers, 4.

42 Ibid., 5 .

43 Ibid.
} 
commonness goes so far that human beings are plural only through their bodies, as if the rational spirit in them were literally one, so that each human being does not have his or her own reason in the same way that each has his or her own body. As against this view we have of course to say that each human being has his or her own intellect and rational powers, no less than each has his or her own body." 44 And here again we find confirmation of Newman's claim that thinking is a living process, for it is not logical structures that think, but persons who make use of them. The essential difference between two human beings is therefore not in their outlook and external features, but in their innermost sphere.

It is true that in some most abstract areas our rational activities may converge. And Descartes opened his Discourse on Method with the well-known declaration that "good sense is, of all things among men, the most equally distributed," after all he propounded his method for the solution of mathematical problems. ${ }^{45}$ There are two sources of human dignity: one is common that we share with others our rational nature; the other one is hidden and incommunicable. And I think it is the latter that is addressed by Newman and Stein. It is like a mark, a sign deep down hidden in our innermost nature. This inward direction gains yet another confirmation: the only way to save one's individuality is to seek it inside not outside; the only way to enrich the world without with one's individual character is build it up inside. And let us say something that may sound paradoxical: the genuine way to save the world is to turn away from the world; the only way to be truly present in the world is to be absent from it.

\section{Others-Empathy}

Incommunicability then is common to all people, but the idiosyncratic character of this incommunicability is what makes us different. Empathy is not primordial in content, that is, we do not know the content of one's consciousness. "Empathy $[\ldots]$ is the experience of foreign consciousness in general, irrespective of the kind of experiencing subject or of the subject whose consciousness is experienced."46 The perceived world and the empathetic world belong to the

\footnotetext{
44 Ibid., 7 .

45 See Descartes, A Discourse on Method. Meditations and Principles, trans. by J. Veitch, London and Melbourne: Everyman's Library, 1984, 3.

46 E. Stein, On the Problem of Empathy, trans. W. Stein, The Hague: Martinus Nijhoff, 1964, 11.
} 
same world. As McCullogh observes, "empathy becomes the foundation for all intersubjective experience." 47

Edith Stein argues that values are objective and we respond to values. We need to comprehend them in order to respond. Values motivate our actions and our responses. In a way, then, values act like imagination. They motivate action, but do not cause it. As Sarah Borden writes: "We cannot 'see' certain values without feeling them."48 And this is what Newman called real apprehension and Stein apperception. And let us note that this unfolding of the individual form into a concrete selfhood is safeguarded, in Newman's doctrine, by the obedience to the dogmatic structure of the Catholic Church. This is a very important but complicated point. On the one hand the true believer (real in his words and deeds) is like the point of reference; on the other this believer is open in conscience to the overall Christian system. His selfhood therefore is not a self-willed licence but a resultant of these two elements. According to Stein, those "who possess the eyes open to the world of values" should "be living as members of the community, in live interaction with its other components."49

Indeed she is talking here about Newman's real assent and the personal readiness to assent to what is real, i.e. to real values. Such a person naturally must "become efficacious outwardly," must become the core of society, the centre of attraction. The centre which does not focus on itself, but on the world of values. Our response to values is "the $<$ most natural $>$ behavior for the person" and it is by the recognition of the values the person approves of that we learn what kind of person she is. ${ }^{50}$ The same was true for Newman. In his view, emotions are a more authentic and immediate portrait of our selfhood than intellectual concepts, which usually constitute a certain safe distance to the world of experience known in experience. Therefore his later philosophy is "no mere psychologism - it is a metaphysics of being as known in experience."

The prerequisite of empathy is the cultivation of profound interpersonal relations. For Newman, the right circumstances of social charity are cultivated in private spheres. Now the requirement of having private relationships as the practical lesson for social charity is very Aristotelian. Newman does not fear that concentration upon individuals will thwart our love of many. Love

47 McCullogh, Edith Stein and Intersubjectivity, in: R. Feist, W. Sweet (eds.), Husserl and Stein, Washington D.C.: The Council for Research in Values and Philosophy, 2003, 130.

48 See S. Borden, Edith Stein, 39.

49 E. Stein, Philosophy of Psychology and the Humanities, 219.

5 Ibid., 227, 228.

51 E. Sillem (ed.), The Philosophical Notebook, vol. 2, 33. See also A. J. Boekraad, The Personal Conquest of Truth, 255-272. 
of many is not superior to the love of individuals. Moreover, once we neglect the latter kind of love, being involved "in the schemes of an expansive benevolence" we shall certainly fail to prepare ourselves for a proper practice of the love of many. Therefore Newman concludes "that the best preparation for loving the world at large, and loving it duly and wisely, is to cultivate an intimate friendship and affection towards those who are immediately about us." ${ }^{.52}$

\section{The Person and Soul Life}

All we have said so far has brought us to some fundamental conclusions with regard to such a varied, complex, and united being as the person. Both Newman and Stein sought to grasp the true nature of the human person. They realized that the proposals, which modern philosophy had provided, were either reductive or, at best, insufficient and, taking into consideration a more profound understanding of the person, were inadequate. In his quest, however, Newman focused on epistemology, at least in his most philosophical endeavour, for he was primarily interested in learning and presenting the way in which the person actually arrives at true knowledge. It can be surmised that even already in his Anglican years Newman felt that the empiricist view, fostered by British empiricism and its proponents, conveyed an incomplete picture of the human person.

What Newman originally, intuitively grasped was later, in the 186os, given the form of an extensive study, particularly in his Grammar of Assent. One might ask: why did this come so late? Such a question, however, would be wrong; each inquirer is on his own individual track towards the truth, no step can be bypassed or borrowed from someone else. Besides, Newman primarily did not deem it fitting to put forward a theoretical investigation when sensus fidelium sufficed. Or perhaps he did not feel ready for the task yet. Stein, for her part, focused on ontology, on what the person is, and how the person comes to acquire knowledge. Like all phenomenologists she strove to come to grips with human experience, i.e. how the person experiences himself and how the person is experienced by others. Newman grappled with British empiricism and the heritage thereof, or in general with modern philosophy and its destructive encroachment upon the area of theology under the guise of liberalism. He noticed how reductive and devastating this intrusion was. This is why he undertook a thorough analysis of the process of knowledge and its basic 
distinction between certainty and certitude. The conclusion Newman arrived at was that the person surpasses intellectual barriers and is capable of assenting to the truth that is beyond comprehension. This investigation was of vital importance, first of all for Newman himself, particularly with the awkwardness he felt towards his Anglican ethos and subsequent realization that there was something wrong with it, especially when this ethos opened the door to liberal intrusions into theology.

Edith Stein, who was a newcomer, or to be precise, a convert to Christianity did not experience this kind of existential need. She was, therefore, if I may put it in this way, inclined to adopt a more investigative approach, indeed the approach of a professional philosopher. Both Newman and Stein, as should be stressed strongly, had grown to a point of being able to witness, with their career or lives, that which they had assented to as the only truth-with this truth being at one with their consciences. Newman desperately needed an answer for his questions as to the genuine depository of Apostolic succession, he even felt compelled to embark upon a thorough historical analysis; Stein, as a philosopher, investigated the ontological grounds of the person. Surprisingly, their divergent paths converged.

In her Philosophy of Psychology and the Humanities, Stein listed the four layers inherent in the person: the physical, the sensory (sentient), the mental, and the personal. These all remain in a dynamic relationship with one another, but the personal layer is of central importance. As Sarah Borden rightly observes, " $[t]$ he most central layer is the person or the personal realm." ${ }^{53}$ The spiritual is the fundamental aspect, and overrules the others, for all these dimensions suggest of the ineffable depth of the spirit. The intriguing element, however, is that the spiritual, while being so decisive, is hidden from view. It lies deeply hidden below what is explicit and visible. Our persons need to awaken what is thus deeply hidden. The difference between the visible and invisible aspects of our very persons can be seen in the difference between causality and motivation. These are two distinct aspects of our knowledge: causality comes from propositions and motivation pertains to persons.

When Newman arrived at Oriel College he noticed, to his horror, that the Christian life of the students was thoroughly neglected. ${ }^{54}$ Such an attitude was a legacy of modernity and the prevailing model of individual choice which had been given a primary position. Oxford University lived in the illusion that the

\section{S. Borden, Thine Own Self, 10.}

54 And yet he was dismissed by the authorities (especially Provost Hawkins), which was strange as Newman only demanded that there be a coherence between theory and practice. 
intellect can assent to religious truths irrespective of how the person who is called upon to give this assent lives. Newman realized that individual choice, this jewel in the modern treasury, bore practical consequences, some of which remained in glaring contradiction to the life of a believer. And if practical conduct was wrong, knowledge also became depraved, for Newman firmly believed that the person is a unity. We cannot think in isolation from what we are.

In a way, Newman and Stein share one intuition, namely, they seek to understand the person, i.e. the finite being, by referring him to the infinite being. Stein expressed her hope in the Finite and Eternal Being that by thorough studying revelation she might gain "a deeper knowledge of finite being." 55 Thus in order to understand the finite being we should begin with the infinite.

Stein uses the metaphor of light to describe our conscious life, a procedure Newman often employed. Conscious life "resembles the lit surface that covers an obscure depth, a depth which manifests itself in and through the medium of the surface. If, then, we want to understand the human being-person, we must penetrate this obscure depth. ${ }^{\text {56 }}$ Our conscious life is like a window that furnishes us with a fairly limited view. We may look inside through it, but we can see only a part of the room, not the whole of the flat, for the window is a conceptual structure, of necessity simplified and generalized.

Human beings carry their being-human. Stein elaborated on this significant issue in her Philosophy of Psychology and the Humanities. We learn in this work that the spirit resides in the soul. The sentient aspect of our being may give hints as to the deep seated soul, but the soul "does not yet emerge at the outset of the sentient development of an individual, but becomes visible only little by little." The soul "is ripening and imprinting that development with its trademark, without the soul's being determined itself by the sentient development. The ripening itself is to be distinguished from [its] showing up within the actuality of living and within character development." In other words, what is apparent on the surface is not exactly what is inside. There is no, if we may put it this way, literary translation of the inside into the soul's expression without. The soul may be awakened by some external circumstances (this is what Newman called the transformation of the notional into the real), therefore "[a]nything and everything can suddenly strike in the depths, to where nothing was able to make headway before. ${ }^{\prime 57}$ This is what Stein means to be awakened to soul life.

55 Stein, Finite and Eternal Being, 355 .

56 Ibid., 364 .

57 Stein, Philosophy of Psychology and the Humanities, 233. 
Now if the soul is not awakened yet, we are living, so to say, on the outskirts of our very beings. We are absorbed "into peripheral experiences if the depth of [our] soul hasn't yet awakened. [...] There's an escaping from the depths to the periphery at the point when a person's soul life turns into torment for her, when the soul is filled with distress." ${ }^{58}$ This state is torment and chaos, for it signifies one's living outside of oneself, or of one's true self; Stein holds that one can continue existing on a mere sentient level.

We may be living in a way as if we had no soul and in total oblivion of what is deeply inside. As this kind of life is continued in the periphery, it resembles the Kierkegaardian aesthetic stage. While living in the periphery (not in oneself) the ego "gets the feeling that it's missing its soul, that it's only a shadow of itself detached from its ownmost being" because when the ego descends into its depth, it "meets up a gaping void in there." 59 Living in the periphery recalls the Newmanian living in notional assents, i.e. in superficial existence. This experience of emptiness must indeed be a terrifying and mind-boggling experience. This state can be called soullessness.

We need to live from out of our soul, thereby illuminating matter; this is how this term "be-souled" should be understood. We need to live an active life. Life is for action, as Newman would say, i.e. the person is present in his acts. It is in action that our life "pours out [our] soul and is its life. [Our soul] itself is a source of life." ${ }^{\prime 6}$ The individual should be living out of the depths, out of his soul. Otherwise we lose the powers of our life. We may be psychologically involved in some activity, taking part in various modes of communication, but without the vital connection with our depth the flow of personal powers begins to trickle and dies down. Wherever our soul is disconnected from the actuality of living, the individual is missing "from behavior and from the visible being of the individual [...] the individual flair or [...] the 'personal touch."' The individual's living then does not come out of the centre of his or her own being, "it is lacking the originality and authenticity of 'core-valent' living."61 Thus, such an individual loses a genuine personality and individuality, loses himself and partakes in 'soul-less' behaviour.

Our personality has its qualitative distinctiveness "that is fashioned out of a core, a formative root. It takes shape in soul, body, and mind; but only in your soul does the individuality achieve clear and unambiguous expression. Neither the material body nor the psyche, as the substantial unity of all the individual's

$\begin{array}{ll}58 & \text { Ibid., 234. } \\ 59 & \text { Ibid. } \\ 6 \text { o } & \text { Ibid. } \\ 61 & \text { Ibid., 235. }\end{array}$


sensuous and soul-mind being and living, is determined through and through by the core. The core certainly supports accessibility for the world of values to whose gradations its depth levels correspond, and with that, the 'character' in the specific sense."62 The personal core - writes Sarah Borden - "is central to our being, we are most at home in the world of values."63 Our core is human and individual - these two elements must be stressed because not only do we belong to a certain species, but we are above all individuals. We are unlike trees of a same kind.

In the Finite and Eternal Being, Stein views the human being as a composition of body, soul, and spirit. ${ }^{64}$ The essence of human beings, however, is spiritual. This is so, primarily, "because personal life is going out of oneself and simultaneously being and abiding within oneself, and because both of these characteristics pertain to the nature of spirit, personal being must always denote spiritual being." ${ }^{5}$ The human person carries the body and the soul and is carried by them. Stein finds the source of spiritual life inside the human being, but this interior is not conceptual so that it could be shown and explained. I have already elaborated on this element earlier. The blessed Carmelite says that " $\mathrm{t}]$ he spiritual life of the human person rises from a dark ground." And she elaborates on this further: "It rises like a flame that illumines, but it is a flame that is nourished by non-luminous matter. And it emits light without being light through and through. The human spirit is visible to itself without, however, being thoroughly transparent. It is capable of illuminating other things without being able to penetrate completely into their being."66

This dark ground is therefore implicit, which means that the human being cannot conceptualize his innermost centre. The body and soul are interconnected. Our physical body is, as was mentioned earlier, be-souled. Edith Stein follows Thomas Aquinas' doctrine of the relationship of the soul as a form of the body. The soul animates the body. The question that is often raised is whether our inner life is only sensory or is it also spiritual. If our inner life were merely sensory, it would be only receptive and responsive to external stimuli which feed the brain with information.

The human being is and is becoming at the same time, for he contains in himself an unfolding form that allows for self-formation. The inner form creates conditions for the bringing of the being to its perfected structure. Thus

62 Ibid., 238.

63 S. Borden, Thine Own Self, 10.

64 See Stein, Finite and Eternal Being, 363.

65 Ibid., 362.

66 Ibid., 364. 
the soul can be regarded as a forming-of-matter and also as a being-in-itself. ${ }^{67}$ Stein stresses "a balance between the external and the internal [...], in people the soul has a meaningful life even apart from the body."68 That is why the human being can make free and authentic choices in response to stimuli which come from without.

If our being is contingent, as it is, it is a "fleeting being," and therefore, as such, it cannot possess its existence. Our being's existence is a gift, and "only he who truly possesses being and who is thus the Lord of being can present such a gift. And only a person can be Lord [...], not Lord of being if anything were exempt from his ontological might, if without him or independent of him there could be either being or not-being." ${ }^{69}$ Stein defines the relation between temporal being and eternal being as follows: "Within itself, eternal being molds (in a non-temporal process) those eternal forms in whose image and likeness it creates the world in time and with time." ${ }^{\prime 70}$ The eternal being is the Lord of being and the Lord of meaning.

Another phrase that Stein uses to make the human person an exceptional being is "personal erectness." The personal being has been awakened, as she masterfully remarked, to a two-directional movement: both outward and inward. The person goes outward when he studies the world, makes use of material objects for his own benefit; and goes inward when he strives to know himself. Newman, as we remember, wrote that only those who are "whole can heal others," with this meaning that we are in possession of ourselves. Stein puts this succinctly when she writes that people can respond to external impressions of freedom because they transcend these impressions; people are "spiritual persons, i.e., carriers of their own lives in a preeminent sense of a personal 'having-oneself-at-hand'", ${ }^{11}$ The problem is that human beings often abandon this exceptional position they possess among other beings, and remain responsive to impressions, a situation Newman would define as living inside shadows and images, with this denoting a being responsive primarily to what comes from without. In this situation the sentient aspect of our being prevails.

In accord with Thomistic Doctrine, Stein holds that created pure spirits are not "the authors of their own being, but have received their being and receive it again and again as an ever-renewed gift during the entire course of their

$\begin{array}{ll}67 & \text { See ibid., 369. } \\ 68 & \text { Ibid., 370. } \\ 69 & \text { Ibid., 106. } \\ 70 & \text { Ibid., 106. } \\ 71 & \text { Ibid., 370. }\end{array}$


existence. ${ }^{72}$ Personal life is therefore free, but limited, relative, and conditioned. The main role of the soul is to mediate "between spirituality and bodily sentient being." ${ }^{73}$ The soul is not a third external element in the triune composition (tri-partition) of body-soul-spirit, but is the site in which body and spirit meet and interact. People, therefore, are both brutes and angels, rather than being either of the two. The soul, so to say, is the room which both body and spirit inhabit.

The I is capable of transcending the sensorial part of the human being and can disengage from it and rise above to a higher sphere. We need not understand this process of disengagement as a kind of isolation, but rather as a mastering of the life of sense. This creating of self by the I is not absolute or unconditioned, for the "I has received the freedom of self-determination as a gift." ${ }^{74}$ This mastering is indeed the system meant by Newman, of which mention has already been made. In like manner the personal life is created and formed by the human person. What is implicitly given as a gift is translated into something explicit. Stein puts it excellently when she writes that the sentient life is for a "dark ground," which awaits personal illumination and being turned into a personal form. I have called the soul here a room, or else it can be called a special site of encounter between body and spirit. The character of the soul is such that it is not "point-like" but rather "spatial." This is an extremely interesting element, for it shows Stein's thought which runs counter to modern thinking, especially counter to Lockean empiricism with its conception of the punctual self that I have already mentioned previously. If the soul in Stein's view is a space, then it is a history. It is not the pure ego. This space is not empty and has its own nature and essence. Thus what has explicitly appeared on the surface is not everything that makes up the person. Each explicit act is accompanied by its implicit (dark) surrounding. There is always much more to the human person than what we can see on the surface. By appropriating to itself what is needed for its own destiny, the soul creates a history for a particular human person whose "essence or nature streams forth from the body and from all personal spiritual acts in a nonconscious and nonvoluntary manner." 75

The person carries his perfection within himself. The person "carries its life out of the fullness of the essence which is resplendent in the awakeness of life, without ever being fully illumined or fully mastered. The person carries

$\begin{array}{ll}72 & \text { Ibid., 370-371. } \\ 73 & \text { Ibid., 371. } \\ 74 & \text { Ibid., 372. } \\ 75 & \text { Ibid., 374. }\end{array}$


this fullness and is simultaneously carried or sustained by this dark and deep ground." ${ }^{\prime 6}$ I have already discussed this element of the innermost and dark interior of the person. It is brought to light by conscious (rational and voluntary) acts of the person. Therefore the human person "resembles pure spirits in its free and conscious mode of life, a life which encompasses and carries its own fullness, but it lags behind them because it arises from and is carried by a dark ground and is incapable of personally forming, illumining, and sovereignly governing the totality of its 'self'." 77 Whatever the person does is only a momentary revelation of some fullness hidden inside, the full revelation of which will come to existence in the life to come. This ever-present evolution of the person, this constant movement, and this self-changing nature are also consonant with Newman's thought. Stein holds that all material structure is penetrated by the spirit. Likewise we come again to the point of form molding matter.

In order to recapitulate, let us say that Stein regards "the person as a carrier in a preeminent sense because a person not only has and embraces, but 'possesses' its essence or nature, which means that a person is master of its own self in several ways." ${ }^{78}$ Stein, like Newman, stressed the importance of reaching oneself, being faithful to oneself, using oneself because the most one can lose is oneself. Subsequently, it becomes apparent that we need to realize our personal vocation in ourselves and with ourselves.

The person is fully self-dependent and endowed with a rational nature. This trait of self-dependence determines the parts of the whole. Self-dependence is inherently combined with incommunicability and subsistence. Thus, the fundamental part of the person is hidden from view, and is implicitly sojourned in oneself. What is fully self-independent is "something that is," with this being "the fullness of the essence."79 The person is both "the carrier of the essence and the composite of carrier and that which is carried-form and fullness." ${ }^{\text {- } 0}$ It is interesting to note that the person is complete in his ontic entity and at the same time is becoming towards perfection. Thus we need to stress the static and dynamic aspects of the human person. At the same time let us stress that this perfection is the subsistence which imparts independence.

The carrier of nature is separated from nature. As Stein stresses, "the thus completed and confined whole—is capable of carrying the properties accruing

\begin{tabular}{ll}
\hline 76 & Ibid., 377. \\
77 & Ibid. \\
78 & Ibid., 408. \\
79 & Ibid., 476. \\
8 o & Ibid.
\end{tabular}


to the essence because in this composite whole the carrier of the nature or essence can and must be distinguished from the essence or nature." ${ }^{81}$

Subsistence does not accrue to the individual substance, but inwardly pertains to the individual substance. Each individual thing has its essence. This essence is shared by all other members of the same species. For instance, Socrates' being human is shared with other humans. Nevertheless Socrates as a human being is, in his particularity, unlike other human beings. Therefore, Stein stresses, "that this essence differs not only numerically but by virtue of a special particularity from the essence of any other human being." ${ }^{2}$

Stein is writing about "primordial confusion," a phrase that echoes Newman's functional disarrangement. In her interpretation, however, this confusion concerns the cosmic mixture (chaos) out of which order emerges. I have already written that the personal carrier is the ground or root principle of the individual being. The person carriers in himself eternity. The course of life of a human being is something unique and unrepeatable. The person is unlike any impersonal something; his life springs from personal being as from a source-as was referenced in Stein earlier. Together with this source the whole individual life is annihilated. Stein seems to be suggesting that the same source of life that springs forth may then be taken on by another individual. Thus, to conclude, the most important difference between two persons is their difference in content. The person imparts his unique particularity, but this root principle is found in the formal structure of the carrier, and this form, as has already been observed, is not communicable.

Human beings are unlike transitory material things, for the former shapes come from the centre of life and the latter objects are in accordance with their species. The role of the individual is of primary importance in relation to species. Unlike lifeless things, humans are under the process of the self-formation "that issues from a vital center" in which "each individual structure is an articulate unity with a meaning and expressive worth of its own, and not merely a transitional stage with respect to the actual end structures [...]."83 Animate creatures, e.g. human beings, undergo self-formation "in the sense of a forming of the individual structure from its vital center and not merely an unfolding of the particularity of the species under the influence of forces effective from the outside. And proportionate to this is a collected power and, springing from it, a stronger activity and efficacy of the self." 84

\footnotetext{
$81 \quad$ Ibid., $476-477$.

82 Ibid., 478.

83 Ibid., 498.

84 Ibid., 498-499.
} 
Human beings are thus active centres and creators of their own selves. They are responsible for their very beings like artists are responsible for the forms they impart to the objects of their artistic expression. Humans are not determined by a historical process, rather they actively participate in it. They can give, to use Newmanian parlance, real assents of their very beings, especially in that "the essential forms of animate beings are living forms and as such capable of unfolding and transformation." 85

Every human being, indeed, shares the same nature with regard to their genus and at the same time, as we have already said, this nature is spiritual, personal, an internal life, self-contained, and is yet self-transcending; it is a world-embracing life that discloses itself to fellow humans. This life is always renewed from these aforementioned sources and determined by the I. Indeed persons are entire worlds. The material aspect of the person brings us closer to the lives of animals and plants, whereas the spiritual aspect transcends these material aspects. The I is an emanating life: it commands over the person, as was noted, by being conscious of the person and molding him freely. The personal I is not a pure ego, as Stein stresses, it is - let us repeat "the portal through which the life of the human person passes on its way from the depth of the soul to the lucidity of consciousness." ${ }^{86}$ In other words, the implicit part of the I emerges to its explicit form. This innermost centre, of which mention has already been made, is not shapeless. It is the true and most genuine part of our selves. Thus, when we are self-centred and self-collected we reach the true centres of our beings. This cannot be given a universal name, notes Stein, and therefore our centres are individualized. Besides, our innermost centre always transcends the explicit form that is given to it. In like manner, we could say that this process of the unfolding of the true essence of the person is never-ending and can never be completed here on earth. Such a process calls for a continuation in the life to come.

Here Stein touches upon the same points Newman mentioned. For him, as we remember, in this world we can only obtain that which has a relative perfection, but once started this process seeks to be continued thereafter; otherwise the very initiation would be nonsensical. The soul has its manifestations, but its essence is ineffable. With a view to this ineffable innermost centre two persons can hardly be compared or their traits enumerated. Hence Stein concludes that "the essential difference in individuals cannot be grasped." ${ }^{87}$

\footnotetext{
85 Ibid., 5 oo.

86 Ibid., 501.

87 Ibid., 502 .
} 
I have already discussed this important point in Edith Stein, namely the fact that the most genuine part of the person is inside in the innermost centre. It resides in the human soul and then embraces the person, "insofar as the person receives its form from this deepest interiority." 88 The conscious I is unique with its individual particularity which cannot be communicated in its entirety.

The soul is immortal as a purely spiritual form and as a spiritual personal substance it is "capable of a supernatural augmentation and elevation of its life [...]." ${ }^{\prime 89}$ The essence of the person, which resides in the soul, is mostly hidden (it is implicit). Let us therefore stress again that the innermost and most authentic nature of human beings remains hidden. In the course of his life the human being assumes, explicitly, a certain style of character. The essence thereof, however, is hidden beneath what is visible. The innermost sphere is hidden in darkness and eludes words in its ineffability. Newman, for his part, calls the soul "the invisible principle which thinks," ${ }^{90}$ with the soul being this principle that makes the person one; a person's oneness is unlike material bodies which are composed of many parts.

Thus, the human being has a dual nature: he is "a spiritual person and he is shaped as a body." ${ }^{11}$ Besides, although the human being holds a dual nature, the person is one being - is spiritual and corporeal together. The person is in a process of development which is on earth forever incomplete. This calls for the completion of undeveloped potentialities, an element that we have already found in Newman and-drawing on St. Thomas - could call a way of imperfection. Stein intimates that "it pertains to the essence of the human being that the individual is a member of the human race and that this individual realizes himself as a whole $[. .$.$] in a humankind." 92$ It is the spiritual nature of humankind that makes humankind called to a communal life, with this being a very strong theme in Newman. This historical aspect of development was extremely important for him. The forms of Christian life, in their course, are combined together to issue in a system. Stein indeed rises to the height of sublime poetry when she writes that in this process "the individual soul comes to bloom in a place prepared for it-prepared by the historical evolution of the people of its earthly homeland and by the generations of its earthly familyand since, after its pure and full unfolding at its predesigned place, the soul is to be inserted as a flower in an eternally imperishable wreath, it does not seem

88 Ibid., 504 .

89 Ibid.

$90 \quad$ Newman, Parochial and Plain Sermons, 907.

91 Stein, Finite and Eternal Being, 506.

92 Ibid., 5 O7. 
fitting to see in its essence or nature a species that can be individualized in a multiplicity of alike structures." ${ }^{\text {3 }}$

All this comes together to denote what Newman called ethos. He himself was reared in his family, circle of friends, university, and in the Church. We develop our potentialities in our individual ways, but never to the degree of perfection. We use ourselves, as Newman opined, for we have been endowed with what we need in our way of development. We must be self-contained and collected, for our true essence is in our innermost depth. There God resides, and hence in finding ourselves we find God. This is vitally important because "those who do not find themselves do not find God either, and do not attain to eternal life."94

Thus the personal is at the same time divine, for it is in the most intimate part of the human core that the source of personal life resides. Here is the human soul which gives unity to the body. Stein observes: "The living soul of natural man has the power to form those material elements which are at its disposal for the building up of its body into a unity, and to maintain and animate this unity in its own structure for a certain length of time. Beyond this, the soul has its inner being and the capacity to receive into itself new life from extraneous sources and thereby to experience an increase, a strengthening, and a heightening of its own life."95

Edith Stein concludes on a mystic note. In sharing our individuality with humankind, we do not lose our distinctive difference, and therefore we can establish the Mystical Body with each part playing a different function. In like manner every individual person, concentrated in soul life, adds to the perfection and beauty of this Body. Stein notes:

In this manner, by the cooperation of nature, freedom, and grace, the body of Christ is built up. Every individual human being is created to be a member of this body. And this is the reason why even on the purely natural level no human being is like the other-we recall that these reflections on the Mystical Body were to aid our understanding of the meaning of human individuality - but every human individual is a variation of the common human essence or nature, an individual structural unit, and simultaneously a constructive part of a structural totality. ${ }^{96}$

\begin{tabular}{ll}
\hline 93 & Ibid., 508. \\
94 & Ibid., 509. \\
95 & Ibid., 519. \\
96 & Ibid., 526.
\end{tabular}


While going into the core of our depth, we acquire the modes of our soul life, with this meaning that inasmuch as we sojourn in our depth we truly live in ourselves. Metaphorically speaking, the ship of our very being meanders between the rocks of images and shadows (to use the Newmanian parlance) on its way to the harbour. The interesting thing here is that living inside does not take on any concrete form, for the life-springing source is an empty form which - in the process of self-formation - takes on a concrete shape. Living the soul life is to be free from attachment to external modes of life, which may draw us away from our true selves; it is to live within one's self. The individual immersing in the soul must constantly free himself from the external forms which revolt for the sake of becoming an individual's essence, thereby postponing or completely disabling one from reaching the source, i.e. the soul life, the personal core vibrating with essential life. I use the term "essential life" because in the innermost centre of our beings is the true residence of the person, not some accidental life styles which our beings may imitate. 